\title{
Systematic Review: which topical agent is more efficacious in the prevention of infections in burn patients?
}

\author{
María Teresa Rosanova ${ }^{a}$, M.D., Daniel Stamboulian ${ }^{b}$, M.D. and Roberto Lede ${ }^{c}$, M.D.
}

\begin{abstract}
SUMMARY
Topical agents are widely used in the care of burn patients; however the efficacy to prevent localinfections and/or sepsis has notbeen clearly established in studies with a high level of evidence. This systematic review was conducted to assess the comparative efficacy among different topical agents.

Material and Methods. The literature search was performed using the Medline database. Key MESH terms were: (burn* or scald*) AND (antibacterial or antibiotic ${ }^{*}$ ) AND (topic*) AND (therap* or prophylax*). Only randomized or quasi-randomized clinical trials, with a primary endpoint of local infection and/or sepsis were included. Studies were scored and classified regarding methodological key issues according to their level of evidence.

Results. The initial search identified 457 studies of which 14 were eligible for final evaluation, and full text was available for 11 of them.

Conclusions. The evidence found in our review does not support differences in efficacy of topical agents to reduce sepsis and/or local infections in burn patients.

Key words: topical agents, burn, infections.
\end{abstract}

http:/ / dx.doi.org/10.5546/aap.2012.eng.298

\section{INTRODUCTION}

According to several authors, topi-

a. Epidemiological Control and Infectology Department. Hospital "Prof. Dr. Juan P. Garrahan".

b. Fundación Centro de Estudios Infectológicos.

c. Instituto Argentino de Medicina Basada en la Evidencia.

Buenos Aires,

Argentina.

E-mail address:

María Teresa Rosanova: margris2@yahoo.com.ar

Conflict of interest:

None.

Received: 2-2-2012

Accepted: 4-11-2012 use is quite extended. Therefore, the question arises regarding which topical agent is more efficacious to prevent infections in the management of burns.

To answer this question, a systematic review of the biomedical literature was conducted; however, since a wide variety of topical anti-infective agents are used in the clinical practice, we thought it would be of interest to start by providing a brief description of them. ${ }^{1}$

\section{Silver-containing compounds}

$1 \%$ Silver Sulfadiazine: Its mechanism of action remains unclear. It is bactericidal against Gram-negative aerobic rods and may be efficacious against fungi.

It does not penetrate the eschar adequately and its main adverse effect is the potential for leukopenia and, rarely, skin reactions. Some studies have demonstrated that it hinders the healing process due to its toxicity on keratinocytes and fibroblasts. ${ }^{1}$ This agent may be combined with cerium nitrate ${ }^{4,6}$ but it should not be used, either alone or in combination, in patients allergic to sulfa medications. Since sulfas may cause jaundice of the basal ganglia (kernicterus), they should not be used in infants younger than 2 months and in pregnant women.

Other silver preparations are available in various forms such as silverimpregnated dressings (Acticoat ${ }^{\circledR}$, among others), that can be replaced every 24 hours.

Silver Nitrate: It is used as a $0.5 \%$ solution. It is bactericidal and does not penetrate the eschar. It must be applied every 2-3 hours and if used on large surface areas it may cause intense fluid and electrolyte imbalance, 
and hyperpigmentation in the treated area. ${ }^{7}$

In some large burn centers, the development of bacterial resistance secondary to silver formulations has been observed after their protracted use. $^{8}$

\section{Antibiotic agents for local use}

0.5\% Mafenide Acetate: This is a local bacteriostatic antibiotic with a broad spectrum of action against Gram-negative and Gram-positive organisms, and certain strains of anaerobes, but with no effect on fungi. Its main adverse effect is the potential for metabolic acidosis. Like sulfadiazine, it may delay healing through the same mechanism. It diffuses into and through eschar better.

Its disadvantage is that it causes pain on treated areas. Due to its short half life it must be applied every 12 hours. ${ }^{1,9}$

Bacitracin: It is a petroleum-based polypeptide antibiotic for local use, effective against Grampositive cocci and bacilli. Its mode of action is by inhibiting the bacterial cell wall synthesis. ${ }^{1,10}$

Framycetin: It is a sulfate salt of neomycin B, bactericidal and active against Gram-positive cocci and Gram-negative rods.

Other agents that have been used for the local treatment of burn wounds, with variable results, are polymixin and neomycin, either alone or combined with bacitracin, and mupirocin.

\section{Disinfecting agents}

Electrolytic Cloroxidant in a hypertonic solution of sodium chloride (Amuchina ${ }^{\circledR}$ ): Initially used as a disinfectant for fruits, vegetables and baby bottles.

Currently it is used to prevent burn-associated infections; however, data available are scarce ${ }^{11} \mathrm{It}$ covers a broad spectrum of Gram-negative rods, Gram-positive cocci, fungi and viruses. Reports have been published about its use for the local treatment of burn wounds. ${ }^{11}$

Clorhexidine and povidone-iodine are among this group.

\section{Natural topical agents}

Honey: This substance is non-toxic and nonirritant. In developing countries it has been used in superficial and intermediate partial-thickness burns; it reduces the bacterial inoculate and favors granulation of burn wounds. ${ }^{12,13}$

Papaya carica: In cases published, a favorable outcome has been described regarding its use to cover burn wounds. ${ }^{14}$

\section{Objective of this review}

To evaluate the comparative efficacy of topical agents most frequently used to prevent infection in burn patients.

\section{MATERIAL AND METHODS}

\section{Inclusion criteria}

a. Randomized or quasi-randomized clinical trials (evidence levels $1 \mathrm{~b}$ or $2 \mathrm{a}$, as per the Center for Evidence-Based Medicine classification system, Oxford University, UK);

b. Studies including only burn patients without an initial infection;

c. Studies comparing the efficacy among topical agents;

d. Development of infection and/or sepsis and/ or time of wound re-epithelization; and/or graft loss as main endpoints;

e. Summary available at least either in Spanish or in English.

\section{Exclusion criteria}

a. More than $20 \%$ of participants lost to followup in any of the groups;

b. Descriptive studies of any type or opinion papers, cohort or case-control studies;

c. Topical agents used in conditions unrelated to burns.

\section{Literature search}

A literature search was undertaken on November 18th., 2011 using the computerized database (PUBMED), and the following key words: (burn $^{*}$ or scald $\left.{ }^{*}\right)$ AND (antibacterial or antibiotic ${ }^{*}$ ) AND (topic*) AND (therap* or prophylax*).

A total of 457 citations were obtained, of which 400 were discarded because the topical agent was unrelated to burns, they were case reports, the topical agents were mentioned as part of the treatment but their role was not investigated, or they were basic experimental or in vitro trials. Another 4 papers were obtained from the reference list of the systematic reviews found.

\section{RESULTS}

Fourteen papers were selected for final evaluation and the text was available in 11 of them.

\section{Excluded studies}

Brown et al. ${ }^{9}$ studied mafenide and its impact in reducing mortality. Mian et al. compared the incidence of sepsis and wound granulation in a series of 20 cases, in which Amuchina ${ }^{\circledR}$ was com- 
pared to silver sulfadiazine. None of them was a randomized or quasi-randomized study. One study was excluded because the summary was neither in English nor in Spanish; two were excluded because they were experimental studies in rats and 5 because they were reviews.

\section{Included studies}

Studies comparing silver-containing topical agents versus other agents

De Gracia et al., ${ }^{4}$ in an open randomized study, assigned the treatment according to a pre-established sequence (evidence level 2a) and compared 30 patients treated with silver sulfadiazine plus cerium nitrate to 30 patients treated only with silver sulfadiazine. Patients included were older than 4 months of age, had a burnt surface area $>15 \%$ of their body surface area (BSA) and were admitted within 24 hours from the injury. The main pre-determined endpoints were wound healing and progression or not to sepsis. The study concluded that patients in the group treated with silver sulfadiazine plus cerium nitrate healed their wounds 8 days before patients treated only with silver sulfadiazine, and additionally, were hospitalized for a shorter time ( 23 vs. 30 days). However, no significant differences were found in burn related infection or sepsis rates.

Ahuja et al. ${ }^{6}$ conducted a quasi-randomized, double blind study in children and adults; treatments were assigned by drawing balls at random (evidence level 2a). They compared the outcome of 20 patients with burns affecting $15-40 \%$ of their BSA in whom they used $1 \%$ framycetin cream, to 20 patients treated with silver sulfadiazine. The main endpoint was bacterial count in the burn wound on days 4 and 7 in both groups. The 2 groups were similar in age and percent of burnt BSA ( $26 \%$ and $28.5 \%$ for framycetin and silver sulfadiazine, respectively). No differences were observed in colony counts of biopsies obtained on days 4 and 7 .

Liao et $\mathrm{al}^{7}$ conducted a multicenter randomized study in 120 children and adults (80 with superficial or intermediate partial-thickness burns, groups $\mathrm{A}$ and $\mathrm{AB}$, and 40 with deep burns, group $B$ or "full-thickness" group). Patients were randomized (the summary does not describe the method employed) to receive silver nitrate or silver sulfadiazine (evidence level 2a). The group treated with silver nitrate exhibited the same antibacterial effect than the group on silver sulfadiazine. Since the paper is written in Chinese, we only had access to the summary.
Muangman et $\mathrm{al}^{8}$ compared, apparently in a quasi-randomized manner, (evidence level 2b), the efficacy of a dressing containing silver sulfadiazine versus $1 \%$ silver sulfadiazine in superficial and intermediate burns affecting less than $25 \%$ of the BSA. Patients were children and adults, and were divided into 2 groups of 25 patients each of similar age, percent of BSA affected and burn etiology. Of those 50 patients, 7 (28\%) developed infection; no significant differences were detected between groups. This paper was also written in Chinese, therefore we only worked with the summary.

\section{Studies comparing topical agents versus placebo}

Livingston et al. ${ }^{10}$ conducted a prospective randomized study (the patient allocation method was not clarified in the summary) in 52 child and adult patients subjected to tangential escharectomy and grafting upon admission (evidence level $2 b$ ). They compared the efficacy of two topical agents: $0.5 \%$ silver nitrate and neomycin $(1 \mathrm{~g} / \mathrm{L})$ plus bacitracin $(50,000 \mathrm{U} / \mathrm{L})$ versus a Ringer's lactate solution (used as placebo), in preventing graft loss due to infection. Seventeen patients (33\%) suffered graft loss, which was attributed to infection in 16.

In patients with burns involving less than $20 \%$ of the BSA, graft loss was not a relevant issue. The use of any of the two antimicrobial drugs resulted in less graft loss in patients with burns affecting $20-40 \%$ of their BSA: 1 out of 14 patients versus 4 out of 6 with Ringer's lactate ( $p<0.05)$. In patients with $>40 \%$ burn of their BSA, $67 \%$ suffered graft loss regardless of the topical agent employed; moreover, $50 \%$ of the patients in the Ringer's lactate group and the whole group that received bacitracin plus neomycin had infections caused by resistant microorganisms or fungi. The authors conclude that in patients with burns involving $20-40 \%$ of their BSA, topical antibiotics are efficacious in reducing infection related graft loss and that neomycin and bacitracin induce antibiotic resistance, whereas silver nitrate does not. Only the summary was available for this study.

Studies that used antibiotics for systemic use administered topically, compared with silver-containing agents

Snelling et al..$^{15}$ conducted a randomized study assigning treatments with a system of odds and even numbers at admission (evidence level 2a). A total of 71 child and adult patients were included; the study compared $1 \%$ silver sulfadiazine versus $0.1 \%$ gentamicin to prevent bacterial coloni- 
zation and sepsis. Patients had to be at 24 hours post burn injury and have more than $10 \%$ of their BSA affected. Children and adults were divided into 2 groups: one with burns involving $11-40 \%$ of the BSA and another group with burns affecting > $41 \%$ of the BSA. Patients with odd numbers were treated with silver sulfadiazine (38 patients) and patients with even numbers received topical gentamicin (33 patients). Pseudomona aeruginosa colonized the burns of $37 \%$ of the 38 patients treated with sulfadiazine and $30 \%$ of the 33 patients treated with gentamicin; of the latter, $21 \%$ had their wound colonized with the same bacterium, but it was resistant to gentamicin. The emergence of resistance warranted discontinuation of gentamicin prophylaxis.

\section{Studies with natural topical agents compared to silver-containing agents}

Malik et al. ${ }^{12}$ evaluated the usefulness of unprocessed honey for the topical treatment of burns affecting less than $40 \%$ of the BSA. The method of randomization employed is not described (evidence level 2a). Patients had to have two contralateral similar body segments (for example: both hands, right and left sides of the abdomen) affected by second degree burns and one intervention was assigned to each segment. They included 150 patients of all ages. Interventions consisted in the topical application of honey or silver sulfadiazine. Re-epithelization occurred faster in sites where honey was used (13.47 days \pm 4.06 versus $15.62 \pm 4.4$ days; $p<0.0001)$.

Subrahmanyam, ${ }^{13}$ in a randomized study (the randomization method was not specified; evidence level 2a), evaluated 50 patients, aged 3 to 60 years, with burns affecting less than $40 \%$ of the BSA. Honey was used in 25 patients and silver sulfadiazine in the remaining 25 . After 21 days of treatment, $100 \%$ of patients treated with honey had healed, compared to $84 \%$ of the other group; these data were confirmed by lesion biopsy.

\section{DISCUSSION}

Numerous topical agents have been proposed and utilized in the management of burn patients. However, in spite of their massive use, evidence regarding their usefulness in preventing the risk of infection is scarce. ${ }^{1-3}$

It has been postulated that silver sulfadiazine reduces the bacterial inoculate, but data showing that it decreases the incidence of infection or sepsis in burn patients are, in fact, scarce. The few studies cited in this review do not suggest that this agent exerts a better effect than others in reducing wound infection or the development of sepsis. ${ }^{4,6-8}$ The chance to slow the healing process and generate reversible leukopenia should be weighted at the time of prescription.

Another problem to consider regarding nonabsorbable antibiotics used locally is the selection of resistant microorganisms, as shown in the study by Livingston et al., ${ }^{10}$ that reported a high rate of resistance in patients treated with bacitracin plus neomycin. This cautions about the possibility of generating resistance with the use of non-absorbable topical antibiotics.

Systemic antibiotics have also been used locally, but Snelling ${ }^{15}$ demonstrated the emergence of gentamicin resistant strains during the course of topical treatment. Since this antibiotic is administered systemically, this finding points out the need to avoid the use of systemic antibiotics as topical agents, since they could later be ineffective in patients requiring their systemic administration because of a severe condition.

In developing countries, honey has been utilized for the treatment of burns. ${ }^{12-14}$ Malik $^{12}$ and Subrahmanyam ${ }^{13}$ demonstrated faster re-epithelization in sites were honey was used compared to those where silver sulfadiazine was used, but burns treated were superficial or intermediate; it was not used in deep burns. Additionally, the small sample size in both studies would limit the validity of these conclusions.

We underscore that this review questions the selection criteria used for one or another anti-infectious agent in the preventive topical treatment of burn wound infections, since the evidence presented here is insufficient to define clear advantages of one agent over another. The conclusions of available studies are weakened by the following caveats: marked heterogeneity of criteria regarding the use of different kinds of topical agents, different ages of patients included (all included children and adults), variable surface and extent of burns, and the various definitions of predetermined endpoints. Moreover, the lack of studies assessing the efficacy of those agents against placebo must be noted. In this review it was not possible to perform a metaanalysis given these limitations.

The potential for certain agents to cause a delay in healing and to generate bacterial resistance is an important reason for caution.

More prospective, randomized and controlled studies are required, with an adequate number of patients, in order to reliably assess the benefits of topical treatment in burn patients. 
TABLE 1. Comparison of studies assessing the efficacy of topical treatment in burn patients

\begin{tabular}{|c|c|c|c|c|c|}
\hline Study & Objectives & Design & $\begin{array}{l}\text { Patients } \\
\text { (n) }\end{array}$ & Conclusions & $\begin{array}{c}\text { Evidence } \\
\text { Level }\end{array}$ \\
\hline $\begin{array}{l}\text { Gracia et al. } \\
2001^{4}\end{array}$ & $\begin{array}{l}\text { To compare the effects of silver } \\
\text { sulfadiazine with cerium nitrate } \\
\text { plus silver sulfadiazine on } \\
\text { wound healing and } \\
\text { development of sepsis. }\end{array}$ & $\begin{array}{l}\text { Open, } \\
\text { randomized }\end{array}$ & $\begin{array}{l}\text { Age: older than } \\
4 \text { months. Thirty } \\
\text { patients treated } \\
\text { with silver } \\
\text { sulfadiazine } \\
\text { versus } 30 \\
\text { treated } \\
\text { with silver } \\
\text { sulfadiazine plus } \\
\text { cerium nitrate. }\end{array}$ & \begin{tabular}{|} 
Patients on cerium nitrate were \\
hospitalized 17.2 days vs. 25.1 \\
days; p: 0.03 , and had a faster \\
wound healing ( 9.5 days \\
versus 14 days, p: 0.007$)$. \\
There was no significant difference \\
in sepsis rate $(1 / 30$ in the cerium \\
group vs. $4 / 30)$ or mortality rate \\
$(1 / 30$ in the cerium group \\
vs. $4 / 30)$.
\end{tabular} & $2 a$ \\
\hline $\begin{array}{l}\text { Ahuja et al. } \\
2009^{6}\end{array}$ & $\begin{array}{l}\text { To compare bacterial count } \\
\text { at day } 4 \text { and } 7 \text { from the initial } \\
\text { lesions in patients who } \\
\text { received framycetin vs. } \\
\text { silver sulfadiazine. }\end{array}$ & $\begin{array}{l}\text { Randomized, } \\
\text { double blind }\end{array}$ & $\begin{array}{c}\text { Twenty child } \\
\text { and adult } \\
\text { patients received } \\
\text { local treatment } \\
\text { with } 1 \% \\
\text { framycetin vs. } \\
20 \text { patients who } \\
\text { received silver } \\
\text { sulfadiazine. }\end{array}$ & $\begin{array}{l}\text { There was no difference } \\
\text { in bacterial count. }\end{array}$ & $2 a$ \\
\hline $\begin{array}{l}\text { Liao et al. } \\
2006^{7}\end{array}$ & $\begin{array}{l}\text { To compare the time of healing } \\
\text { and the antibacterial effect of } \\
\text { silver sulfadiazine vs. silver } \\
\text { nitrate in superficial and } \\
\text { intermediate burns. }\end{array}$ & $\begin{array}{l}\text { Randomized, } \\
\text { multicenter }\end{array}$ & $\begin{array}{l}\text { One hundred } \\
\text { and twenty } \\
\text { child and adult } \\
\text { patients: } \\
60 \text { treated with } \\
\text { sulfadiazine vs. } \\
60 \text { treated with } \\
\text { silver nitrate. }\end{array}$ & $\begin{array}{c}\text { Time of healing of superficial } \\
\text { burns in the silver nitrate group } \\
\text { was } 9.5 \pm 2.7 \text { days vs. } \\
10.8 \pm 3.4 \text { days in the } \\
\text { sulfadiazine group. } \\
\text { Percent of healed tissue at } \\
\text { day } 7 \text { was } 77.9 \pm 20.5 \% \text { with } \\
\text { silver nitrate vs. } 67.3 \pm 22.6 \% \text {, } \\
\text { with sulfadiazine ( } \mathrm{p} \leq 0.01) \text {. } \\
\text { In intermediate burns, time of } \\
\text { healing was } 21.5 \pm 4.8 \text { days with } \\
\text { silver nitrate vs. } 23.3 \pm 6.4 \text { days } \\
\text { with sulfadiazine (p } \leq 0.01 \text { ). } \\
\text { Percent of healing at day } 7 \\
\text { was } 86.6 \pm 15.9 \% \text { with nitrate vs. } \\
78.5 \pm 17.7 \% \text { with sulfadiazine } \\
\text { (p } \leq 0.01 \text { ). }\end{array}$ & $2 a$ \\
\hline $\begin{array}{l}\text { Muangman } P, \\
2006^{8}\end{array}$ & $\begin{array}{l}\text { To compare the efficacy of silver } \\
\text { sulfadiazine vs. Acticoat } \AA \text { in } \\
\text { superficial and intermediate } \\
\text { burns affecting less than } 25 \% \text { of } \\
\text { the BSA. }\end{array}$ & $\begin{array}{l}\text { Quasi- } \\
\text { randomized } \\
\text { study }\end{array}$ & $\begin{array}{l}\text { Fifty child } \\
\text { and patients }\end{array}$ & $\begin{array}{l}\text { There was no difference } \\
\text { between groups in the } \\
\text { incidence of infection } \\
\text { or hospital stay. }\end{array}$ & $2 b$ \\
\hline $\begin{array}{l}\text { Livingston } \\
\text { et al. } \\
1990^{10}\end{array}$ & $\begin{array}{l}\text { To compare the effects of } \\
\text { silver nitrate vs. neomycin } \\
\text { plus bacitracin vs. } \\
\text { Ringer's lactate } \\
\text { on graft loss. }\end{array}$ & Randomized & $\begin{array}{l}\text { Fifty two } \\
\text { children } \\
\text { and adults }\end{array}$ & $\begin{array}{l}\text { Among patients with burns } \\
\text { affecting } 20-40 \% \text { or more of their } \\
\text { BSA, graft loss was: } 1 / 14 \text { with } \\
\text { antibiotics vs. } 4 / 6 \text { with } \\
\text { Ringer's lactate }(\mathrm{p}<0.05) \text {. } \\
\text { Among patients with burns } \\
\text { affecting }>40 \% \text { of the BSA, graft } \\
\text { loss was } 67 \% \text {, regardless of the } \\
\text { topical agent used. }\end{array}$ & $2 b$ \\
\hline
\end{tabular}




\begin{tabular}{|c|c|c|c|c|c|}
\hline $\begin{array}{l}\text { Snelling et } \\
\text { al. } \\
1978^{15}\end{array}$ & $\begin{array}{l}\text { To compare silver sulfadiazine } \\
\text { vs. gentamicin in preventing } \\
\text { colonization and sepsis in burns } \\
\text { affecting more than } 10 \% \\
\text { of the BSA, at } 24 \text { hours } \\
\text { from the initial injury. }\end{array}$ & Randomized & $\begin{array}{l}\text { Seventy one } \\
\text { child and } \\
\text { adult patients }\end{array}$ & $\begin{array}{l}\text { Tissue colonization by } \\
\text { Pseudomonas spp was found in } \\
37 \% \text { of the } 38 \text { patients treated with } \\
\text { sulfadiazine and in } 30 \% \text { of the } 33 \\
\text { patients treated with gentamicin; } \\
21 \% \text { of Pseudomonas spp were } \\
\text { resistant to gentamicin. }\end{array}$ & $2 a$ \\
\hline $\begin{array}{l}\text { Malik et } \\
\text { al. } \\
2010^{12}\end{array}$ & $\begin{array}{l}\text { To compare the efficacy of } \\
\text { honey vs. silver sulfadiazine } \\
\text { in superficial burns affecting } \\
<40 \% \text { of the BSA. }\end{array}$ & Randomized & $\begin{array}{l}\text { One hundred } \\
\text { and fifty child } \\
\text { and adult } \\
\text { patients }\end{array}$ & $\begin{array}{l}\text { Reepithelization time was shorter } \\
\text { in the honey group than in the } \\
\text { sulfadiazine group }(13.47 \pm 4.06 \\
\text { vs. } 15.62 \pm 4.4 \text { days; p: } 0.0001)\end{array}$ & $2 a$ \\
\hline $\begin{array}{l}\text { Subrahman- } \\
\text { yam M. } \\
1998^{13}\end{array}$ & $\begin{array}{l}\text { To compare the time of } \\
\text { healing with silver sulfadiazine } \\
\text { vs. honey. }\end{array}$ & $\begin{array}{c}\text { Randomization } \\
\text { method } \\
\text { not } \\
\text { specified }\end{array}$ & $\begin{array}{l}\text { Fifty } \\
\text { children and } \\
\text { adults }\end{array}$ & $\begin{array}{c}\text { A hundred percent of patients } \\
\text { treated with honey healed by } \\
\text { day } 21, \text { vs. } 84 \% \\
\text { in the other group (p: } 0.01)\end{array}$ & $2 \mathrm{a}$ \\
\hline
\end{tabular}

\section{REFERENCES}

1. Palmieri T, Greenhalgh D. Topical treatment of pediatric patients with burns: a practical guide. Am J Clin Dermatol 2002;3(8):529-34.

2. Atiyeh B, Costagliola M, Hayeck S, Dibo S. Effect of silver on burn wound infection control and healing: review of the literature. Burns 2007;33(2):139-48.

3. Mackway-Jones K. Best evidence topic report. Towards evidence-based emergency medicine: best BETs from the Manchester Royal Infrmary. Emerg Med J 2006;23(4):300.

4. de Gracia CG. An open study comparing topical silver sulfadiazine and topical silver sulfadyazine cerium nitrate in the treatment of moderate and severe burns. Burns 2001;(27):67-74.

5. Garner JP, Heppell PS. Cerium nitrate in the management of burns. Burns 2005;31(5):539-47.

6. Ahuja RB, Gupta A, Gur R. A prospective double blinded comparative analysis of framycetin and silver sulphadiazine as topical agents for burns: a pilot study. Burns 2009;35(5):672-6.

7. Liao ZJ, Huan JN, Lv GZ, Shou YM, Wang ZY. Multicenter clinical study of the effect of silver nitrate ointment on the partial thickness burn wounds. Zhongua Shao Shang Za Zhi 2006;22(5):359-61.

8. Muangman P, Chuntrasakul C, Silthram S, Suvanchote S, et al. Comparison of efficacy of $1 \%$ silver sulfadiazine and Acticoat for treatment of partial thickness burn wounds. J Med Assoc Thai 2006;89(7):953-8.
9. Brown TP, Cancio LC, McManus AT, Mason AD Jr. Survival benefit conferred by topical antimicrobial preparations in burn patients: a historical perspective. J Trauma 2004;56(4):863-6.

10. Livingston DH, Cryer HG, Miller FB, Malangoni MA, et al. A randomized prospective study of topical antimicrobial agents on skin grafts after thermal injury. Plast Reconstr Surg 1990;86(6):1059-64.

11. Mian EU, Gianfaldoni R, Mian M. Topical treatment of burn wounds with chloroxidating solution and silver sulfadiazine: a comparative study. Drugs Exp Clin Res 1991;17(4):243-52.

12. Malik KI, Malik MA, Aslam A. Honey compared with silver sulphadiazine in the treatment of superficial partial thickness burns. Int Wound J 2010;7(5):413-7.

13. Subrahmanyam M. A prospective randomised clinical and histological study of superficial burn wound healing with honey and silver sulphadiazine. Burns 1998;24(2):157-61.

14. Starley IF, Mohammed P, Schneider G, Bickler S. The treatment of paediatric burns using topical papaya. Burns 1999;25(7):636-9.

15. Snelling CF, Ronald AR, Waters WR, Yaworski DS, et al. Comparison of silver sulfadiazine and gentamicin for topical prophylaxis against burn wound sepsis. Can Med Assoc J 1978;119(5):466-70. 